\title{
VERTEBRATE FAUNA ASSOCIATES OF THE WEDGE-TAILED SHEARWATER, PUFFINUS PACIFICUS, COLONIES OF ROTTNEST ISLAND: INFLUENCE OF AN ECOSYSTEM ENGINEER
}

\author{
by Wesley J. Bancroft, J. Dale Roberts and Mark J. Garkaklis
}

(with five text-figures and three tables)

\begin{abstract}
Bancroft, W.J., Roberts, J.D. \& Garkalis, M.J. 2008 (31:x): Vertebrate fauna associates of the Wedge-tailed Shearwater, Puffinus pacificus, colonies of Rotrnest Island: influence of an ecosystem engineer. Papers and Proceedings of the Royal Society of Tasmania 142(1): 21-30. https://doi.org/10.26749/rstpp.142.1.21 ISSN 0080-4703. School of Animal Biology, M092, University of Western Australia, Crawley WA 6009, Australia (WJB, JDR, MJG), and 3 Gregona Place, Kalamunda WA 6076, Australia (WJB*). *Author and address for correspondence. Email: wes@graduate.uwa.edu.au.
\end{abstract}

\begin{abstract}
Wedge-tailed Shearwaters, Puffinus pacificus, engineer the ecosystem by digging burrows in which they nest. This has been previously shown to affect the soil and vegetation properties of their colonies. Here we report on field surveys employed ro investigate how associated vertebrate fauna respond to physical habitat modification by shearwaters. The study area was species poor, with only one mammal, and three reptile species detected in 1440 Elliott trap and 720 pitfall trap nights across a 13-month period. Nineteen bird species were recorded from 98 survey days. Relative to an area of uncolonised heath, we observed an increase in the abundance of King's Skinks, Egernia kingii, and a decrease in the abundance of House Mice, Mus musculus, and West Coast Ctenotus, Ctenotus fallens, in the shearwater colony. The survival rates of King's Skinks and House Mice were not affected by Wedge-tailed Shearwater presence. Bird species richness was less in the colony $\left(9.2 \pm 0.5\right.$ species month $\left.{ }^{-1}\right)$ than the heath $\left(11.5 \pm 0.2\right.$ species month $\left.^{-1}\right)$, and the composition of the two communities was different. We suggest that ecosystem engineering by Wedge-tailed Shearwaters is a major determinant of fauna associates of their colonies and offer direct and indirect mechanisms to explain the patterns of species occurrence observed.
\end{abstract}

Key Words: Wedge-tailed Shearwater, Puffinus pacificus, ecosystem engineering, burrow, Rottnest Island, avifauna, Egernia kingii, Mus musculus, Ctenotus fallens.

\section{INTRODUCTION}

Wedge-tailed Shearwaters, Puffinus pacificus (J.F. Gmelin, 1789), are pelagic seabirds that nest in burrows on islands in the Indian and Pacific oceans. They have been described as ecosystem engineers because they disrupt resource flows within their colonies as a consequence of their physical modification of habitat (Jones et al. 1994, Bancroft et al. 2004b). On Rottnest Island, Western Ausrralia, burrowing by an expanding colony of Wedge-tailed Shearwaters has created $5.1 \mathrm{~km}$ of tunnels ha ${ }^{-1}$, displaced $210 \mathrm{t}^{\mathrm{t}}$ soil ha $\mathrm{h}^{-1}$ and significantly modified physical and chemical soil properties (Bancroft et al. 2004a, b, Bancroft et al. 2005a, b). These soil perturbations correlate with changes in plant diversity, structure and productivity (Bancroft et al. 2005c). The impact that burrowing by the birds has on the island fauna has yet to be investigated.

Burrowing may affect fauna by two main mechanisms: directly, by providing a habitat resource, the burrow; and indirectly, by altering the edaphic or botanical characteristics of a site via biopedturbation (Jones et al. 1994, 1997, Kinlaw 1999, Whitford \& Kay 1999). These mechanisms have been best studied in mammals and the direct use of mammalian burrows by non-burrowing taxa has been well documented (e.g., mole, Scalopus spp.; prairie dog, Cynomys spp.; rat, Eliurus spp.; and kangaroo rat, Dipodomys spp. systems; Scheffer 1945, Campbell \& Clark 1981, Hawkins \& Nicoletto 1992, Goodman 1994). Burrows can benefit associated animals by providing shelter from predators or climate, a site for socialisation or communication, or by conveying physiological advantages (Kinlaw 1999). Avian burrows are also directly utilised by co-occurring fauna:
Tiger Snakes, Notechis scutatus (Peters, 1861), cohabit Short-tailed Shearwater, Puffinus tenuirostris (Temminck, 1835), burrows (Serventy et al. 1971); Tuatara, Sphenodon punctatus (Gray, 1842), utilise Fairy Prion, Pachyptila turtur (Kuhl, 1820), burrows (Newman 1987); and King's Skinks, Egernia kingii (J.E. Gray, 1838), and Dibbler, Parantechinus apicalis (J.E. Gray, 1842), use Wedge-tailed Shearwater burrows (K. Wolfe, pers. comm., Chapple 2003). The indirect impacts of burrowing mammals on faunal communities are predominantly through the disruption of food webs, and have been associated with changes in species diversity (Whicker \& Detling 1988, Ceballos et al. 1999, Kinlaw 1999) and abundance (Whicker \& Detling 1988, Hawkins \& Nicoletto 1992). Nutrient and trophic cascades have been implicated in the increased abundance of fauna in burrowing seabird colonies (Markwell \& Daugherty 2002) and post-breeding survival of male Dibbler (Wolfe et al. 2004) but otherwise the impact of avian ecosystem engineers is poorly known.

Here we follow our previous studies of the ecosystem engineering impact of Wedge-tailed Shearwaters on soil and vegetation by determining the vertebrate fauna associates of their colonies on Rottnest Island. We used Elliott and pitfall trapping to survey for amphibians, reptiles and mammals, and area searches for avifauna. Capture-mark-recapture techniques were used to estimate population size and survival rates for the two dominant, non-avian vertebrates: House Mice, Mus musculus Linnaeus, 1758, and King's Skinks. Areas with and without shearwater burrows were compared to investigate the impacts that ecosystem engineering by shearwaters has on the abundance and species composition of the associated fauna community. 
TABLE 1

The percentage of surveys in which bird species were recorded present on, in or above the colony and heath

\begin{tabular}{|c|c|c|c|c|c|c|c|c|c|c|c|c|c|c|c|c|c|c|c|c|c|c|c|c|}
\hline & \multicolumn{12}{|c|}{ Colony } & \multicolumn{12}{|c|}{ Heath } \\
\hline & 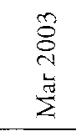 & 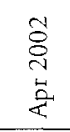 & 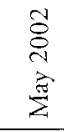 & 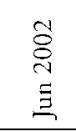 & 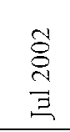 & 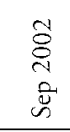 & $\begin{array}{l}\stackrel{1}{8} \\
\stackrel{8}{0} \\
\stackrel{0}{0}\end{array}$ & 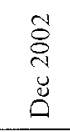 & 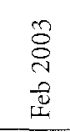 & 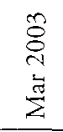 & 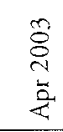 & 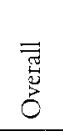 & 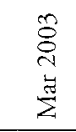 & 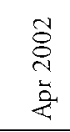 & 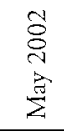 & $\begin{array}{l}\text { oे } \\
\stackrel{\sim}{1} \\
\Xi \\
\end{array}$ & 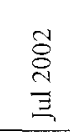 & 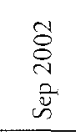 & 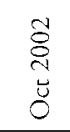 & 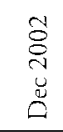 & $\begin{array}{l}\infty \\
8 \\
\stackrel{8}{1} \\
\stackrel{0}{\nu} \\
\tilde{L}\end{array}$ & 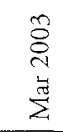 & 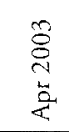 & 氶 \\
\hline \multicolumn{25}{|l|}{ Terrestrial species } \\
\hline Ring-necked Pheasant, Phasianus colchicus & - & - & - & - & - & - & - & - & - & - & - & - & 91 & 80 & 100 & 100 & 89 & 100 & 100 & 90 & 100 & 75 & 100 & 93 \\
\hline Wedge-tailed Shearwater, Puffinus pacificus & 100 & 100 & 25 & & & 75 & 78 & 100 & 100 & 100 & 100 & 71 & - & - & - & - & - & - & - & - & - & - & - & - \\
\hline Mountain Duck, Tadorna tadornoides & - & - & - & 50 & 67 & 25 & - & - & - & - & 20 & 15 & - & - & - & - & - & - & - & - & - & - & - & - \\
\hline Painted Button-quail, Turnix varia & - & - & - & - & - & - & - & - & - & - & - & - & - & - & - & 22 & - & 11 & - & 22 & 17 & - & - & 7 \\
\hline Ruddy Turnstone, Arenaria interpres & 100 & - & - & - & - & - & - & - & - & - & 100 & 18 & - & - & - & - & - & - & - & - & - & - & - & - \\
\hline Pied Oystercatcher, Haematopus longirostris & 9 & - & 43 & 25 & 56 & 38 & - & - & - & - & 100 & 25 & - & - & - & - & - & - & - & - & - & - & - & - \\
\hline Silver Gull, Larus novaehollandiae & - & - & 14 & 75 & 100 & 75 & 33 & 10 & - & - & 80 & 35 & - & - & - & - & - & - & 11 & - & - & - & & 1 \\
\hline Laughing Turtle-dove, Streptopelia senegalensis & - & - & - & - & - & - & - & - & - & - & - & - & 55 & 100 & 86 & 75 & 89 & 88 & 100 & 100 & 89 & 100 & 100 & 89 \\
\hline White-browed Scrubwren, Sericornis frontalis & - & - & - & 25 & - & - & - & - & 11 & - & - & 4 & 100 & 100 & 100 & 100 & 100 & 100 & 100 & 100 & 100 & 100 & 100 & 100 \\
\hline Singing Honeyeater, Lichenostomus virescens & 18 & 20 & 71 & 100 & 33 & 25 & - & 40 & - & - & 80 & 35 & 100 & 100 & 100 & 100 & 100 & 100 & 100 & 100 & 100 & 100 & 100 & 100 \\
\hline White-fronted Chat, Epthianura albifrons & 100 & 100 & 100 & 100 & 33 & 75 & 89 & 90 & 44 & 25 & 100 & 78 & & & 29 & 75 & 100 & 100 & 100 & 100 & 100 & 100 & 100 & 73 \\
\hline Australian Raven, Corvus coronoides & 55 & 60 & 71 & - & 11 & 13 & 33 & 10 & - & - & - & 23 & 100 & 100 & 100 & 100 & 100 & 100 & 100 & 80 & 100 & 75 & 100 & 96 \\
\hline Australasian Pipit, Anthus novaeseelandiae & - & - & - & - & - & - & - & - & - & - & - & - & 18 & - & - & - & - & - & - & - & - & - & 20 & 3 \\
\hline Silvereye, Zosterops lateralis & - & - & - & 50 & - & - & 11 & 30 & - & - & 40 & 12 & 100 & 100 & 100 & 100 & 100 & 100 & 100 & 100 & 100 & 100 & 100 & 100 \\
\hline Aerial species - foraging & - & - & - & - & - & - & - & - & - & - & - & - & - & - & - & - & - & & & & - & & - & - \\
\hline Osprey, Pandion haliaetus & 100 & 100 & 100 & 100 & 100 & 100 & 100 & 100 & 100 & 100 & 100 & 100 & 100 & 100 & 100 & 100 & 100 & 100 & 100 & 100 & 100 & 100 & 100 & 100 \\
\hline Black-shouldered Kite, Elanus axillaris & - & - & - & - & - & - & - & - & - & - & - & - & 27 & - & - & - & - & - & - & - & - & - & - & 5 \\
\hline Nankeen Kestrel, Falco cenchroides & 18 & 13 & - & 25 & - & 13 & 33 & - & 11 & 33 & - & 13 & 27 & 25 & 10 & 38 & - & 25 & 56 & 20 & 22 & 33 & 30 & 26 \\
\hline Welcome Swallow, Hirundo neoxena & 100 & 100 & 100 & 100 & 78 & 88 & 89 & 80 & 100 & 100 & 80 & 91 & 100 & 100 & 100 & 88 & 78 & 100 & 89 & 80 & 100 & 100 & 80 & 92 \\
\hline Tree Martin, Hirundo nigricans & 91 & 100 & 90 & 100 & 78 & 100 & 100 & 70 & 100 & 83 & 90 & 92 & 91 & 100 & 90 & 100 & 89 & 88 & 100 & 80 & 100 & 83 & 90 & 92 \\
\hline Aerial species - in transit & - & - & - & - & - & - & - & - & - & - & - & - & - & - & - & - & - & - & - & - & - & - & - & - \\
\hline Crested Tern, Sterna bergii & 45 & 50 & 30 & 13 & 11 & 75 & 67 & 60 & 67 & 50 & 40 & 46 & 45 & 38 & 30 & 25 & 11 & 75 & 56 & 50 & 56 & 33 & 40 & 42 \\
\hline Fairy Tern, Sterna nereis & - & 13 & - & - & - & - & 33 & 50 & - & - & - & 9 & - & - & - & - & - & - & 33 & 50 & - & - & - & 8 \\
\hline Fork-tailed Swift, Apus paciffcus & 9 & - & - & - & - & - & - & - & - & - & - & 1 & 9 & - & - & - & - & - & - & - & - & - & - & 1 \\
\hline
\end{tabular}




\section{MATERIALS AND METHODS}

The study was conducted on Rottnest Island $\left(32^{\circ} 00^{\prime} \mathrm{S}\right.$, $115^{\circ} 31^{\prime} \mathrm{E}$ ), southwest Western Australia (fig. 1), between March 2002 and April 2003, and focused on the largest two Wedge-tailed Shearwater colonies on the island, Radar Reef, and Cape Vlamingh (Bancroft et al. 2004a). Colonies were vegetated by low, ruderal and, predominantly, non-native species (Bancroft et al. 2005c). Plant species diversity on the colonies was low, with much of the colony surface dominated by a monoculture mat of Iceplant, Mesembryanthemum crystallinum L. (Bancroft et al. 2005c). Surrounding uncolonised areas comprised low (c. $1 \mathrm{~m}$ ), moderately diverse, native heath vegetation (Bancroft et al. 2005c). Detailed descriptions of the vegetation of the colony and non-colony (heath) areas are provided by Bancroft et al. 2005c.

A single trapping location was selected (using randomly generated mapping co-ordinates) in each colony, and in the heath within c. $50 \mathrm{~m}$ of each colony's boundary. Birds were surveyed by area searches and non-avian, terrestrial vertebrates were surveyed by both pitfall and Elliott trapping. The pitfall trapping was limited to the Radar Reef colony because there was a risk of public interference with the pitfall traps at Cape Vlamingh. Both trapping methods exclude the capture of larger animals (see trap dimensions below). The only such species that was known to occur within the study area was the Quokka, Setonix brachyurus (Quoy \& Gaimard, 1830). A pilot study of Quokkas suggested that their abundance was too low to warrant further investigation.

\section{Bird surveys}

Bird species were recorded as present/absent in the colony and heath while conducting Elliott and pitfall trapping, and other work. The area of heath surveyed was equivalent to the respective colony area (approximately 4 ha). Birds were surveyed on 98 days over a period of 13 months: March (11 days), April ( 8 days), May (10 days), June ( 8 days), July $(9$ days), September ( 8 days), October ( 9 days), and December 2002 (10 days), and February (9 days), March (6 days) and April 2003 (10 days). Recordings were made each day between 0700 and 0900 , and 1400 and 1600 . Species were classified as: (i) terrestrial, if observed predominantly on the heath or colony locations, (ii) aerial - foraging, if observed on the wing above the locations and were using them as a foraging resource, or (iii) aerial - in transit, if predominantly observed above the locations in transit. The three aerial - in transit species (see table 1) were excluded from subsequent analyses.

Occurrence data were used to calculate Shannon-Weiner diversity index $(H)$, and the equitability $(E)$ for the colony and heath communities (see Krebs 1999). Similarly, two community comparison indices were calculated; the coefficient of Jaccard $\left(S_{j}\right)$ and percentage similarity $(P$, see Krebs 1989). Data from each month were treated separately.

\section{Elliott trapping}

At each trapping location, 12 Elliott traps $(325 \times 85 \times 95$ $\mathrm{mm}$ treadle, box-traps; Elliott Scientific, Upwey Victoria) were arranged in a line at $5 \mathrm{~m}$ intervals. Traps were baited with a mix of rolled oats, sardines and peanut butter. Traps were opened for five nights on six survey occasions: March,

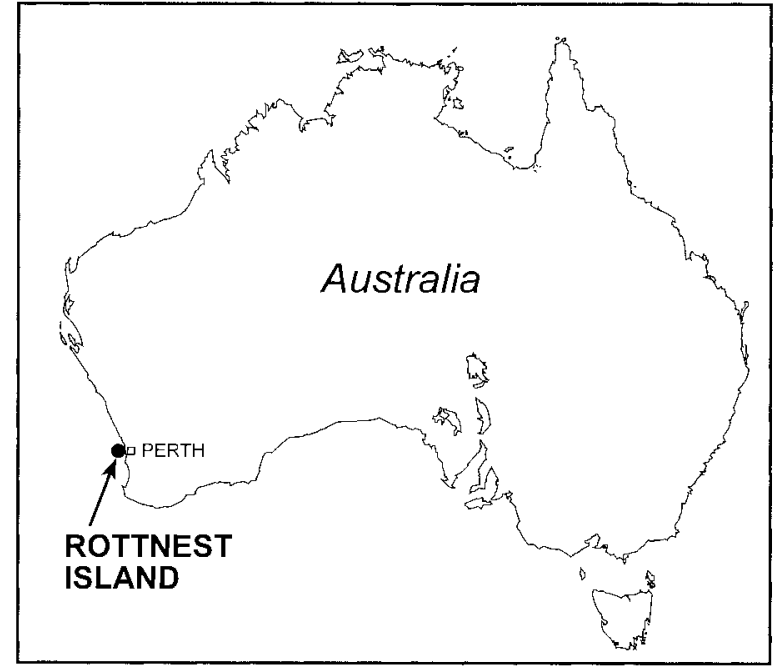

FIG. 1 - Location of Rottnest Island.

May, July, October, December 2002 and February 2003 Traps were checked in the early morning. Captured animals were individually marked by toe- (reptiles) or ear-clipping (mammals), and immediately released.

Data from both trapping locations within the colony or heath were pooled for analysis. Chi-squared $\left(\chi^{2}\right)$ tests were used to analyse frequency data. Repeated-measures (RM) ANOVA was used to analyse capture rates. MANOVA was used to concurrently analyse the new capture and recapture rates of multiple species (variables). The Jolly-Seber model equations presented by Krebs (1999) and Program MARK (Gary White, Colorado State University) were used to derive population estimates, and survival and recapture probabilities from the capture-mark-recapture data. Assumptions of this model are provided by Krebs (1999). Student t-tests were used to compare population estimates (paired in time) and movements of colony and heath animals.

\section{Pitfall trapping}

At each location, 12 unfenced, unbaited, PVC pitfall traps (150 $\mathrm{mm}$ diameter $\mathrm{x} 400 \mathrm{~mm}$ depth) were spaced in a line at $5 \mathrm{~m}$ intervals. As the traps were initially dug in, wire mesh was placed beneath the trap to prevent animals from burrowing out of the traps, while allowing free drainage of water. Traps were opened for four consecutive nights in each of June, July, October, December 2002 and February 2003. Traps were checked in the early morning. When not in use, traps were sealed with metal lids and covered with soil. Captured animals were released, unmarked.

Reptile data (all species) were pooled for analyses. Total reptile and mouse abundances for each location were compared using a $\chi^{2}$ test. RM-ANOVA was used to analyse capture rates.

\section{Burrow use by King's Skinks}

Internally-winding cotton spools were attached to the base of the tail of 14 King's Skinks (six at Cape Vlamingh, eight at Radar Reef) trapped by Elliott trapping in December 2002 (during the period of highest reptile activity). The free end of the cotton was tied to vegetation adjacent to the point of capture and the animal released. We returned 24 hours later, recaptured the animal, and used the cotton tracer to determine the number of burrows it had entered. 


\section{RESULTS}

\section{Bird surveys}

Twenty-two species were recorded on, in or over the colony or heath. Of these, 19 were observed using the colony or heath as a resource (terrestrial and aerial-foraging species; table 1 ). Ten species were recorded on both the colony and heath, with four exclusively in the colony: Wedge-tailed Shearwater; Mountain Duck, Tadorna tadornoides (Jardine \& Selby, 1828); Ruddy Turnstone, Arenaria interpres (Linnaeus, 1758); and Pied Oystercatcher, Haematopus longirostris Vieillot, 1817. Five species were recorded exclusively in the heath: Ring-necked Pheasant, Phasianus colchicus Linnaeus, 1758; Painted Buttonquail, Turnix varia (Latham, 1802); Laughing Turtle-dove, Streptopelia senegalensis (Linnaeus, 1766); Australasian Pipit, Anthus novaeseelandiae Vieillot, 1818; and Black-shouldered Kite, Elanus axillaris (Latham, 1802). By definition of our locations, Wedge-tailed Shearwaters were only observed in the colony and our records reflect birds present in burrows during the survey period. Mountain Ducks were mainly observed in winter months, when up to six birds foraged through the low colony vegetation. Ruddy Turnstones were present on the colony in both the autumn of 2002 and 2003 , but at all other times of the year were absent from the location. Flocks of up to 40 turnstones foraged over the colony surface, frequently probing beneath senescent vegetation for invertebrates. Similarly, Pied Oystercatchers foraged, usually in pairs or threes, in the colony during autumn, but also extended their use of the location through winter.

Based on species richness, the two communities were moderately similar (co-efficient of Jaccard; $S_{j}=0.53$ ). Accounting for the frequency of species presence, the communities were still similar (percentage similarity, $P=$ $50.8 \%$ ). Both locations were similar in diversity (ShannonWeiner diversity index, $H$ ); for the colony $H=0.91$ and for the heath $H=0.96$. Species were evenly encountered (equitability index, $E$ ) at each location; for the colony $E$ $=0.79$ and for the heath, $E=0.81$. The mean monthly species richness was significantly less in the colony $(9.2$ \pm 0.5 , range $6-11)$ than the heath $(11.5 \pm 0.2$, range $10-13$; paired t-test, $\mathrm{t}_{10}=4.1, P=0.002$ ).

\section{Elliott trapping}

Three measures were used to assess the relative use of colony and heath locations by animals captured by Elliott trapping: total individuals captured, capture rate and estimated population size. Three species were captured in the 1440 Elliott trap nights: King's Skink (91 individuals, 501 captures), House Mouse (287 individuals, 469 captures) and West Coast Ctenotus, Ctenotus fallens Storr, 1974, (five individuals, five captures). West Coast Ctenotus was excluded from analyses due to the low number of captures.

Totalled across all surveys, there were significantly more King's Skinks (52) and fewer House Mice (115) individuals in the colony than in the heath (39 and 172 respectively; $\chi^{2}$ $=8.2$, d.f. $=1, P=0.004)$. The mean number of animals (new and recaptured) captured trap ${ }^{-1}$ night $^{-1}$ showed the same, significant trends for both King's Skink (RM-ANOVA, $\left.\mathrm{F}_{1,94}=8.3, P<0.001\right)$ and House Mouse (RM-ANOVA, $\mathrm{F}_{1,238}=11.8, P=0.001$; fig. 2). Subsequent analysis treated new and recaptured animals as separate variables and showed that this trend was attributable to differences in rates of capture of both groups (MANOVA, $F_{4,1425}=$
10.72, $P<0.001)$. There was also a significant effect of trapping month on capture rate (MANOVA, $\mathrm{F}_{10,2854}=$ 8.96, $P<0.001$; fig. 2). Capture rate differed significantly between all months, with the exception of October and December 2002 for King's Skink (SNK, $P=0.767$ ), and March 2002 and February 2003 (SNK, $P=0.817$ ) for House Mouse. There was a peak in the capture rate of House Mice in the winter (July) survey, and the maximum number of King's Skinks was caught in spring and early summer (October and December). Colony and heath capture rates behaved consistently over time (no significant interaction between location and month; MANOVA, $\mathrm{F}_{10,2854}=0.84$, $P=0.587)$. While overall there was a significantly higher capture rate of House Mice in the heath, during July the capture rate in the colony rose to equal that of the heath (SNK, $P=0.294$; fig. 2).

Analysis of capture-mark-recapture data produced four separate estimates of population size for both species at each location (fig. 3). The colony supported a larger population of King's Skinks (paired t-test, $\mathrm{t}_{3}=11.0, P=0.002$ ), and a smaller population of House Mice $\left(\mathrm{t}_{3}=3.4, P=0.044\right)$ than the heath. Comparison of the means and standard errors presented in table 2 suggests that, within species, there was no difference in the survival and recapture probabilities of colony and heath animals.

Seventy King's Skinks and 118 House Mice were recaptured on at least one occasion. Frequency distributions of the maximum distance moved by recaptured animals are shown in figure 4 . For individuals that moved only within a trapping location (see fig. 4), the mean distance moved did not differ for colony and heath animals (King's Skink, $\mathrm{t}_{59}=0.4, P=0.680$; House Mouse, $\left.\mathrm{t}_{105}=0.4, P=0.700\right)$. For these animals, the average maximum distance moved (direct distance between traps) was 11.6 $\pm 1.1 \mathrm{SE} \mathrm{m}$ for King's Skink (range $0-32.4, \mathrm{n}=61$ ) and $15.0 \pm 1.3 \mathrm{SE} \mathrm{m}$ for House Mouse (range $0-55.4, \mathrm{n}=107)$. Nine King's Skinks $(9.9 \%$ of all individuals captured) and 11 House Mice (3.8\%) moved between trapping locations. Two movements of King's Skinks were of particular note. One animal moved at least $770.7 \mathrm{~m}$ (between July and October 2002), and the other $730.5 \mathrm{~m}$ (between December 2002 and February 2003). The remaining King's Skink moved between 56.3 and $76.9 \mathrm{~m}$ (fig. 4). Between-location movements by House Mice ranged from 55.3 to $81.1 \mathrm{~m}$. Animals originally marked in the colony and heath did not differ in their between-location movements (t-test, King's Skink, $\mathbf{t}_{7}=0.1, P=0.922$; House Mouse, $\mathrm{t}_{9}=1.8, P=0.110$ ).

\section{Pitfall trapping}

One species of mammal (House Mouse) and three species of reptile (West Coast Ctenotus; King's Skink; and Western Paleflecked Morethia, Morethia lineoocellata (Duméril \& Bibron, 1839)) were captured in the 720 trap nights (numbers of captures are presented in table 3). Species richness was higher in the heath (3) than the colony (2). The total number of captured House Mice and reptiles (pooled captures) differed significantly between the three locations surveyed by pitfall trapping $\left(\chi^{2}=23.9\right.$, d.f. $\left.=1, P<0.001\right)$. There were more mice in the colony ( 45 captures) than the heath (22), and more reptiles in the heath (19) than the colony (1).

The rate of capture (animals trap ${ }^{-1}$ night $^{-1}$ ) differed significantly between locations for House Mice (RMANOVA, $F_{1,94}=5.1, P=0.027$ ), and reptiles (RM-ANOVA, $\mathrm{F}_{1,94}=14.1, P<0.001 ;$ fig. 5). For both groups there was a 


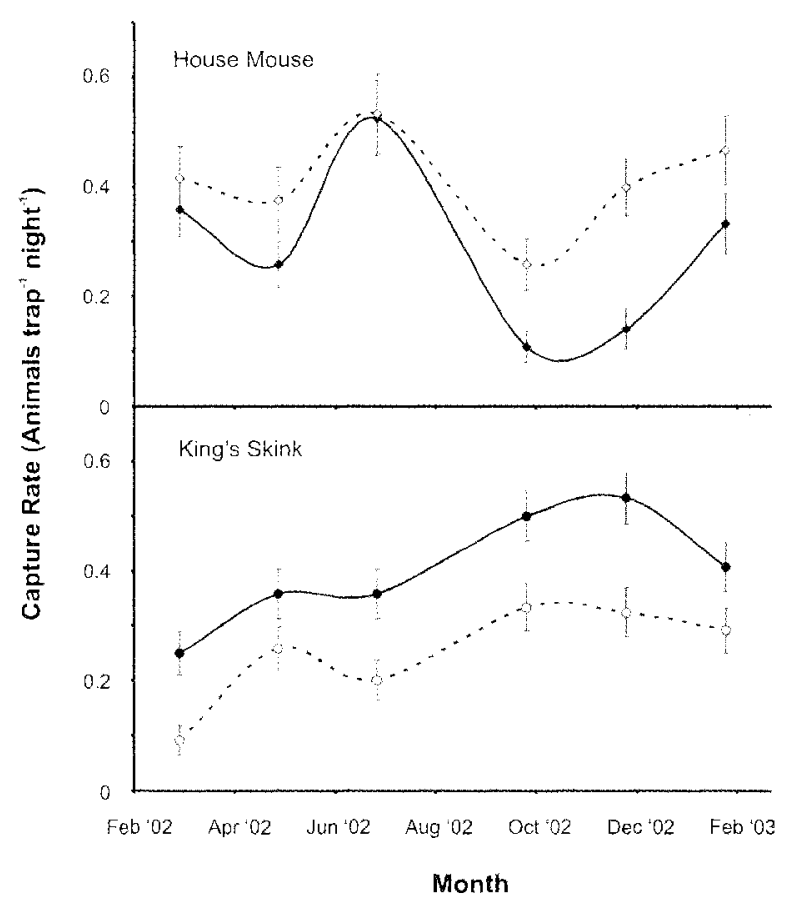

FIG. 2 - The rate of capture of King's Skinks and House Mice in the colony (solid line) and heath (dashed line) for the six Elliott trapping surveys. Error bars represent standard errors.

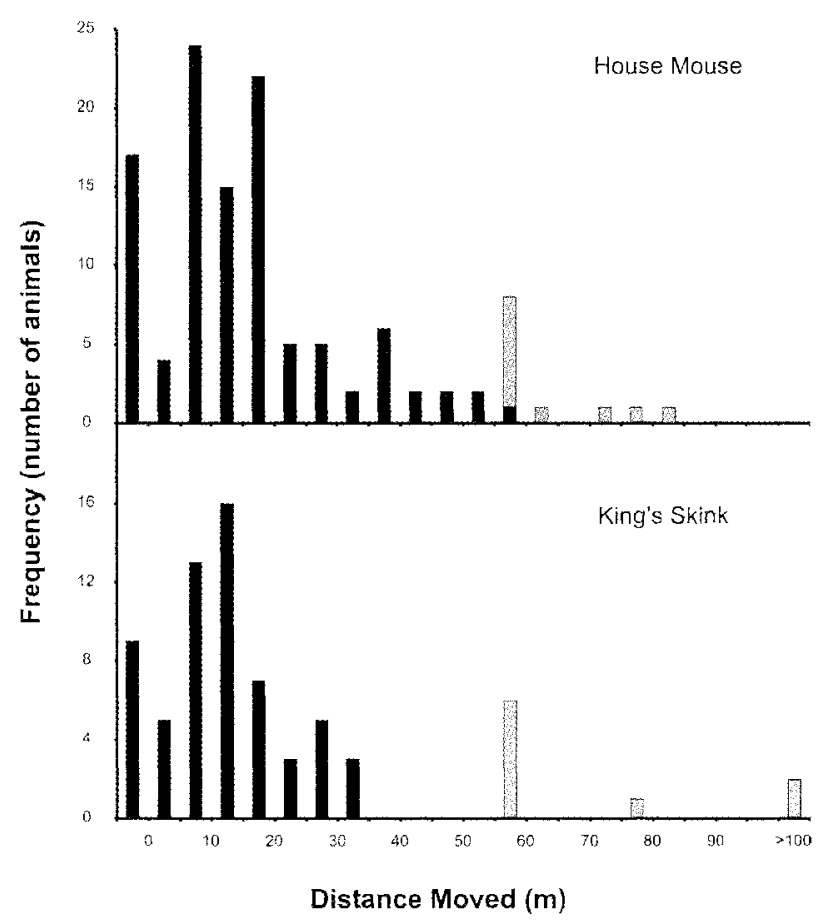

FIG. 4-Frequency histogram of the maximum distance moved within (black bars) and between (grey bars) trapping locations by King's Skinks $(N=70)$ and House Mice $(N=118)$.

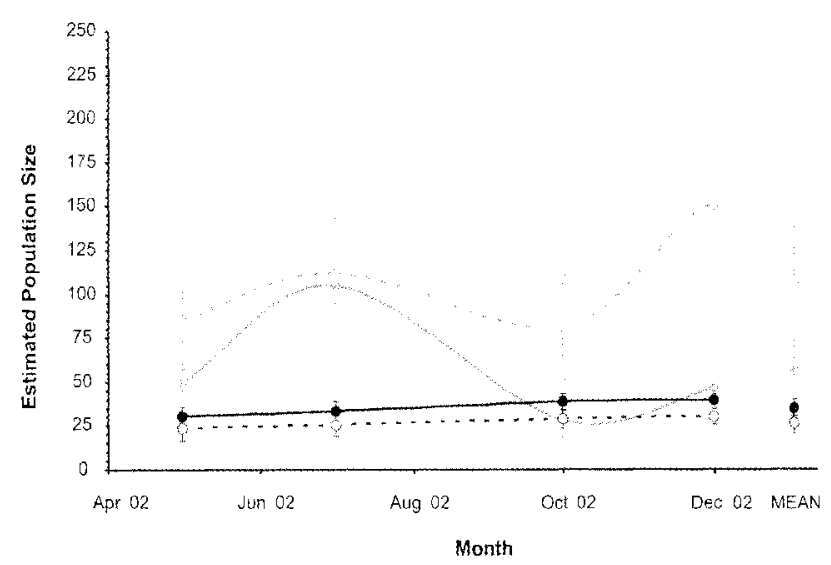

FIG. 3 - Estimated total population sizes of King's Skinks (circles) and House Mice (diamonds) in the colony (solid points and lines) and heath (open points and dashed lines) areas surveyed. Error bars represent standard errors.

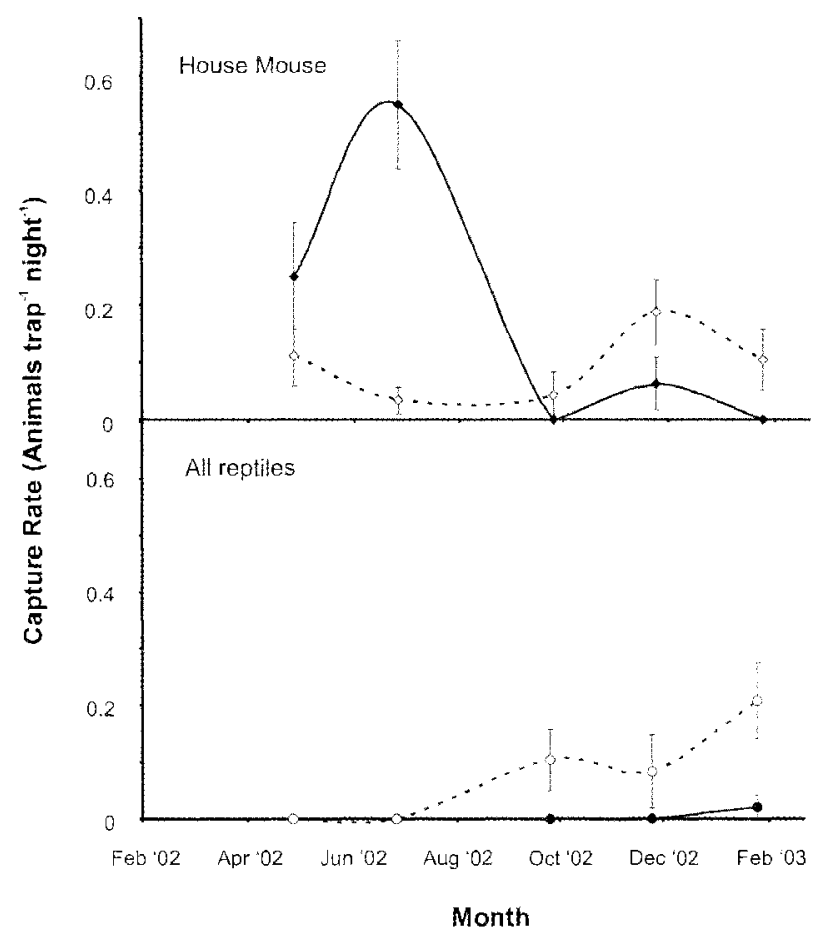

FIG. 5 - The rate of capture of House Mice and all reptiles in the colony (solid line), and heath (short-dashed line) for the five pitfall trapping surveys. Error bars represent standard errors. 
TABLE 2

Annual probability of survival and recapture for King's Skink and House Mouse in the colony and heath

\begin{tabular}{llll}
\hline Species & Location & $\begin{array}{c}\text { Probability of } \\
\text { survival }\end{array}$ & $\begin{array}{c}\text { Probability of } \\
\text { recapture }\end{array}$ \\
\hline $\begin{array}{l}\text { King's Skink, } \\
\text { Egernia kingii }\end{array}$ & Colony & $0.906 \pm 0.032$ & $0.744 \pm 0.045$ \\
& & $(0.823-0.952)$ & $(0.645-0.822)$ \\
& Heath & $0.930 \pm 0.037$ & $0.676 \pm 0.059$ \\
& $(0.814-0.978)$ & $(0.551-0.780)$ \\
House Mouse, & Colony & $0.676 \pm 0.082$ & $0.234 \pm 0.061$ \\
Mus musculus & & $(0.501-0.813)$ & $(0.135-0.374)$ \\
& Heath & $0.676 \pm 0.055$ & $0.324 \pm 0.054$ \\
& & $(0.560-0.774)$ & $(0.228-0.438)$ \\
\hline
\end{tabular}

Values given \pm SE. $95 \%$ confidence limits in parentheses

significant effect of trapping occasion (RM-ANOVA, $F_{4,94}$ $>7.1, P<0.001$ for both cases).

\section{Burrow use by King's Skinks}

On average King's Skinks utilised $6.07 \pm 0.27 \mathrm{SE}$ burrows lizard $^{-1}$ day $^{-1}$ (range 4-8).

\section{DISCUSSION}

Wedge-tailed Shearwaters on Rottnest Island have engineered the vegetation from a reasonably diverse, waist-height heath to a low mat of vegetation that is dominated by Iceplant (Bancroft et al. 2005c). It is highly likely that these changes in vegetation structure and composition are responsible for the differences in avifauna species richness and composition that we observed. Two shorebird species that are usually associated with the beaches and salt lakes were attracted to the colonies. Senescent colony vegetation produced conditions that were similar to the rotting seaweed banks that are often frequented by these species (Saunders \& de Rebeira 1993). While the low, open areas of shearwater colony attracted a different guild of foraging birds from the adjacent heath, it also excluded other modes of foraging. Ground feeding granivores such as Ring-necked Pheasant, Laughing Turtledove and Painted Button-quail were not present in the colony. Iceplant produces very small, wind-blown seeds that are unlikely to support these birds, whereas heath provides a greater diversity of larger seed-bearing species (Bancroft $e t$ al. 2005c). The granivores, especially Ring-necked Pheasant and Painted Button-quail, prefer cryptic, enclosed habitat (Marchant \& Higgins 1993, Saunders \& de Rebeira 1993) so would be expected to avoid the open, exposed colony.

King's Skinks and House Mice dominated the trapping studies. The two species appear to respond to the presence and physical impact of Wedge-tailed Shearwaters (Bancroft $e t$ al. 2004b, Bancroft et al. 2005a) in opposing manners. The shearwater colonies supported a greater number of King's Skinks (as measured by number of new animals, individuals, capture rate and estimated population size) than the adjacent heath, but there were fewer House Mice in the colony than the heath. Given the massive modification of habitat, and the disruption of edaphic and vegetation characteristics of
TABLE 3

The total number of captures of species caught by pitfall trapping at each of the two locations

\begin{tabular}{lcc}
\hline Species & \multicolumn{2}{c}{ Locations } \\
\cline { 2 - 3 } & Colony & Heath \\
\hline House Mouse, Mus musculus & 45 & 22 \\
West Coast Ctenotus, & - & 17 \\
Ctenotus fallens & - & 2 \\
King's Skink, Egernia kingii & - & - \\
Western Pale-flecked Morethia, & 1 & \\
Morethia lineoocellata & & \\
\hline
\end{tabular}

the colonies via biopedturbation and burrowing (Bancroft et al. 2004a, b, 2005a, b, c), it is highly likely that ecosystem engineering by the shearwaters is responsible (at least in part) for these patterns. Several possible mechanisms, direct and indirect, may explain the patterns observed.

The two major, direct functions of burrows are to provide shelter from the environment or predators, and to convey physiological benefits (Reichman \& Smith 1990, Kinlaw 1999). King's Skink is an ectothermic reptile; it behaviourally thermoregulates and is therefore dependent on the surrounding environment for sources of heat or shade (Withers 1992). The shearwater colonies would be particularly favourable locations for this species because the burrows provide a relatively constant temperature environment and an excellent source of shade in hot conditions (Whittow et al. 1987). Throughout the year Rottnest Island burrow temperatures range from $13.2^{\circ}$ to $22.7^{\circ} \mathrm{C}$ (W. Bancroft, unpubl. data), but the ground surface temperatures range from $10.8^{\circ}$ to $47.3^{\circ} \mathrm{C}$ (Bancroft et al. $2004 \mathrm{~b}, 2005 \mathrm{a}$ ). It is known that other reptiles, such as snakes, use burrows for thermoregulation (Serventy et al. 1971, Whitaker \& Shine 2002) and we frequently observed King's Skinks shuttling in and out of burrows. The House Mouse is an endothermic mammal and is less dependent on the surrounding environment to thermoregulate. While burrows can certainly assist the thermal physiology of endothermic animals they are by no means essential for House Mice (Withers 1992, Moro \& Morris 2000). Both species may also use burrows to avoid predation (Strahan 1995, Cogger 2000). On Rottnest Island, the major predators of both species are likely to be birds of prey (Saunders \& de Rebeira 1993) and burrows are particularly effective for avoiding aerial predators (Kinlaw 1999). While House Mice readily construct their own burrow systems (Avenant \& Smith 2003) and numerous mouse burrows were observed throughout the study, King's Skinks prefer the burrows of other animals (Triggs 1996, Chapple 2003). Again, House Mice are somewhat independent of the surrounding physical habitat resources.

Biopedturbation by shearwaters may indirectly affect the cohabiting fauna via changes to the soil and flora, and flowon effects through food webs. King's Skink is omnivorous and feeds on a wide variety of foods including vegetation, invertebrates, carrion and seabird eggs (Bush et al. 1995, Chapple 2003). The House Mouse is also omnivorous but on islands its diet is more limited than King's Skink and 
comprises mostly invertebrates, with some supplementary plant material (Le Roux et al. 2002, Moro \& Bradshaw 2002, Smith et al. 2003). Shearwaters reduce plant species diversity, and the structural complexity of colony vegetation (Bancroft et al. 2005c) and this may reduce arthropod diversity (Abbott 1976). Such a mechanism may indirectly limit the House Mouse population and the broader dietary range of King's Skinks may buffer this species against perturbations in food supply caused by shearwater biopedturbation. Wolfe (2004), however, noted an increased abundance of invertebrates in the shearwater colonies on Whitlock and Boullanger islands (c. $200 \mathrm{~km}$ to the north of Rottnest Island). Markwell \& Daugherty (2002) also found an increase in invertebrate abundance on New Zealand islands inhabited by burrowing seabirds. If this is true for Rottnest Island, then other processes must be acting to limit mouse numbers. Regrettably we have no data on invertebrate abundance or diversity in the Rottnest Island shearwater colonies to test this, but the seasonal pattern in House Mouse abundance supports its exclusion by shearwaters. The House Mouse population in the colony was suppressed (relative to the heath) for the majority of the year, except for the winter survey, where the population rose to equal that of the heath (see figs 2,3 ). This is also the period when the shearwaters were completely absent from the island. Absence of the shearwaters apparently permits the colony House Mouse population to reach the level recorded in the heath.

Indeed, the direct and indirect effects of the burrows or biopedturbation may be overlain with direct interactions between the burrower and the cohabiting fauna. King's Skinks are diurnal and House Mice are predominantly nocturnal (Strahan 1995, Chapple 2003). The majority of shearwaters forage at sea during the day and return to their colony after dark (Marchant \& Higgins 1990) so there would be relatively little interaction with active King's Skinks but considerable overlap with active House Mice. Predation of mice or skinks by Wedge-tailed Shearwaters has not been reported, but House Mice fall within the size range of fish taken by the birds, so may be a potential food source (Barker \& Vestjens 1989, Strahan 1995, Schultz \& Klomp 2000). The Sheathbill, Chionis minor Hartlaub, 1841, is of a similar body size to the Wedge-tailed Shearwater and is known to predate on mice (V.R. Smith, pers. comm.). At c. $220 \mathrm{~g}$, adult King's Skinks are unlikely to be consumed by shearwaters (c. $380 \mathrm{~g}$, Dunning 1993, Storr et al. 1999, Schultz \& Klomp 2000). Both skinks and mice feed on seabird eggs or attack chicks (Bush et al. 1995, Cuthbert \& Hilton 2004) so may be a potential threat to nesting shearwaters. Short-tailed Shearwaters appear to tolerate predators (Tiger Snakes, Serventy et al. 1971) although there are several reports of other burrowers defending their burrows and evicting snakes (Halpin 1983, Newman 1987, Randall et al. 2000). Wedge-tailed Shearwaters apparently tolerated King's Skinks, as many of the burrows utilised by the skinks were also actively used by the birds, including incubating adults.

Our data, therefore, show that Wedge-tailed Shearwaters had a significant effect on the King's Skink and House Mouse populations on the western end of Rottnest Island but that the main causes of these impacts were most likely different mechanisms. We suggest that the increased King's Skink abundance in the shearwater colonies was most likely a result of physical changes in the environment caused by Wedgetailed Shearwater biopedturbation (ecosystem engineering;
Jones et al. 1994, 1997). In contrast, the House Mouse populations within the colonies appeared to be suppressed by the presence of the shearwaters themselves. Some effects of ecosystem engineering by Wedge-tailed Shearwaters on the House Mice populations cannot be completely discounted without further investigation.

There was seasonality to the capture rate of both species. The capture rate of King's Skinks peaked in spring, was consistent across both locations, and presumably reflected the period when the animals were most active (see also How \& Shine 1999). The capture rate of House Mice was highest in winter, and was probably driven by an increase in population size as a result of increased food availability. Many plants at the study locations fruit or shed their seed at this time of year (e.g., Acanthocarpus preissii Lehm., Olearia axillaris (DC.) Benth., Rhagodia baccata (Labill.) Moq.; Rippey \& Rowland 1995) and there is a rapid increase in the germination and growth of new plants (W. Bancroft, unpubl. data). Invertebrate abundance also increases during the wetter months in this region (Recher et al. 1996, Majer et al. 2003).

The movements of mice and skinks were not influenced by whether they lived within the colony, or in the heath. We found no difference in the survival rates between mice or skinks that lived in the colony, and lived in the heath. So, while the abundance of King's Skinks and House Mice was affected by Wedge-tailed Shearwaters, the survival rates of these species were not. To our knowledge these are the first empirical data to test the effect that an ecosystem engineer has on a life history trait of another species.

\section{ACKNOWLEDGEMENTS}

This study was funded by the School of Animal Biology, University of Western Australia, and was conducted under Western Australian Department of Conservation and Land Management licence number SF003964 and UWA Animal Ethics approval number 01/100/175. We thank the Rottnest Island Authority for their co-operation and we are indebted to Ron Wooller for the loan of field equipment. Thanks to Phil Withers who provided the cotton spools and to Ian Warburton, Brenden Metcalf and Robert 'Wildman' Davis for their assistance in the field. We extend our thanks to Valdon Smith and an anonymous referee for their insightful and constructive comments that improved the manuscript. We also thank the editor, Margaret Davies, for her guidance and assistance in preparing the final paper.

\section{REFERENCES}

Abbott, I. 1976: Comparisons of habitat structure and plant, arthropod and bird diversity between mainland and island sites near Perth, Western Australia. Australian Journal of Ecology 1: 275--280

Avenant, N.L. \& Smith, V.R. 2003: The microenvironment of house mice on Marion Island (sub-Antarctic). Polar Biology 26: 129-144.

Bancroft, W.J., Garkaklis, M.J. \& Roberts, J.D. 2004a: Continued expansion of the Wedge-tailed Shearwater, Puffinus pacificus, nesting colonies on Rottnest Island, Western Australia. Emu 104: 79-82.

Bancroft, W.J., Garkaklis, M.J. \& Roberts, J.D. 2005a: Burrow building in seabird colonies: a soil forming process in island ecosystems. Pedobiologia 49: 149-165. 
Bancroft, W.J., Hill, D. \& Roberts, J.D. 2004́b: A new method for calculating volume of excavated burrows: the geomorphic impact of Wedge-tailed Shearwater burrows on Rotenest Island. Functional Ecology 18: 752-759.

Bancroft, W.J., Roberts, J.D. \& Garkaklis, M.J. 2005b: Burrow entrance attrition rate in Wedge-tailed Shearwater Puffinus pacificus colonies on Rottnest Island, Western Australia. Marine Ornithology 33: 23-26.

Bancroft, W.J., Roberts, J.D. \& Garkaklis, M.J. 2005c: Burrowing seabirds drive decreased diversity and structural complexity, and increased productivity in insular-vegetation communities. Australian Journal of Botany 53: 231-241.

Barker, R.D. \& Vestjens, W.J.M. 1989: The Food of Australian Birds: Vol 1. Non-passerines. CSIRO Division of Wildlife and Ecology, Lyneham, Australian Capital Territory: 557 pp.

Bush, B., Maryan, B., Browne-Cooper, R. \& Robinson, D. 1995: A Guide to the Reptiles and Frogs of the Perth Region. University of Western Australia Press, Nedlands, Western Australia: $226 \mathrm{pp}$.

Campbell, T.M. \& Clark, T.W. 1981: Colony characteristics and vertebrate associates of White-tailed and Black-tailed Prairie Dogs in Wyoming. American Midland Naturalist 105: 269-276.

Ceballos, G., Pacheco, J. \& List, R. 1999: Influence of prairie dogs (Cynomys ludovicianus) on habitat heterogeneity and mammalian diversity in Mexico. Journal of Arid Environments 41: 161-172.

Chapple, D.G. 2003: Ecology, life-history, and behavior in the Australian Scincid genus Egernia, with comments on the evolution of complex socialicy in lizards. Herpetological Monographs 17: 145-180.

Cogger, H.G. 2000: Reptiles and Amphibians of Australia. 6th edtn. Reed New Holland, Sydney, Australia: 808 pp.

Cuthbert, R. \& Hilton, G. 2004: Introduced house mice Mus musculus: a significant predator of threatened and endemic birds on Gough Island, South Atlantic Ocean? Biological Conservation 117: 483-489.

Dunning, J.B. (ed.) 1993: CRC Handbook of Avian Body Masses. CRC Press, Inc., Boca Raton, Florida, USA: 371 pp.

Goodman, S.M. 1994: A description of the ground burrow of Eliurus webbi (Nesomyinae) and case of cohabitation with an endemic bird (Brachypteraciidae, Brachypteracias). Mammalia 58: 670-672.

Halpin, Z.-T. 1983: Naturally occurring encounters between Black-tailed Prairie Dogs (Cynomys ludovicianus) and snakes. American Midland Naturalist 109: 50-54.

Hawkins, L.K. \& Nicoletto, P.F. 1992: Kangaroo rat burrows and the spatial organisation of ground-dwelling animals in semiarid grassland. Journal of Arid Environments 23: 199-208.

How, R.A. \& Shine, R. 1999: Ecological traits and conservation biology of five fossorial "sand-swimming" snake species (Simoselaps: Elapidae) in south-western Australia. Journal of Zoology 249: 269-282.

Jones, C.G., Lawton, J.H. \& Shachak, M. 1994: Organisms as ecosystem engineers. Oikos 69: 373-386.

Jones, C.G., Lawton, J.H. \& Shachak, M. 1997: Positive and negative effects of organisms as physical ecosysrem engineers. Ecology 78: 1946 1957.

Kinlaw, A. 1999: A review of burrowing by semi-fossorial vertebrates in arid environments. Journal of Arid Environments 41: 127-145.

Krebs, C.J. 1999: Ecological Methodology. Addison-Welsey Educational Publishers, Inc, Menlo Park, California, USA: $624 \mathrm{pp}$.

Le Roux, V., Chapuis, J.L, Frenot, Y. \& Vernon, P. 2002: Diet of the house mouse (Mus musculus) on Guillou Island, Kerguelen archipelago, Subantarctic. Polar Biology 29: $49-57$.

Majer, J.D., Recher, H.F., Graham, R. \& Gupta, R. 2003: Trunk invertebrate faunas of Western Australian forests and woodlands: Influence of tree species and season. Austral Ecology 28: 629-641.

Marchant, S. \& Higgins, P.J. (eds) 1990: Handbook of Australian, New Zealand and Antarctic Birds. Volume 1: Ratites to Ducks. Oxford University Press, Melbourne, Australia: 1408 pp.

Marchant, S. \& Higgins, P.J. (eds) 1993: Handbook of Australian, New Zealand and Antarctic Birds. Volume 2: Raptors to Lapwings. Oxford University Press, Melbourne, Australia: $1048 \mathrm{pp}$.

Markwell, T.J. \& Daugherty, C.H. 2002: Invertebrate and lizard abundance is greater on seabird-inhabited islands than on seabird-free islands in the Marlborough Sounds, New Zealand. Ecoscience 9: 293-299

Moro, D. \& Bradshaw, S.D. 2002: Diets and predictions of feeding rate of house mice and Lakeland Downs short-tailed mice inhabiting an arid-zone island in Western Australia. Australian Journal of Zoology 50: 249-265.

Moro, D. \& Morris, K. 2000: Movements and refugia of Lakeland Downs short-tailed mice, Leggadina lakedownensis, and house mice, Mus domesticus, on Thevenard Island, Western Australia. Wildlife Research 27: 11-20.

Newman, D.G. 1987: Burrow use and population densities of Tuatara (Sphenodon punctatus) and how they are influenced by Fairy Prions (Pachyptila turtur) on Stephens Island, New Zealand. Herpetologica 43: 336-344.

Randall, J.A., Rogovin, K.A. \& Shier, D.M. 2000: Antipredator behavior of a social desert rodent: footdrumming and alarm calling in the great gerbil, Rhombornys opiums. Behavioral Ecology and Sociobiology 48: 110-118.

Recher, H.F., Majer, J.D. \& Ganesh, S. 1996: Seasonality of canopy invertebrate communities in eucalypt forests of eastern and western Australia. Australian Journal of Ecology 21: $64-80$.

Reichman, O.J. \& Smith, S.C. 1990: Burrows and Burrowing Behaviour by Mammals. In Genoways, H. H. (ed.): Current Mammalogy. Volume 2. Plenum Press, New York, USA: 596 pp.

Rippey, E. \& Rowland, B. 1995: Plants of the Perth Coast and Islands. University of Western Australia Press, Nedlands, Western Australia: 292 pp.

Saunders, D.A. \& de Rebeira, C.P. 1993: The Birds of Rottnest Island. DAS and CPdeR, Guildford, Western Australia: $118 \mathrm{pp}$.

Scheffer, T.H. 1945: Burrow associations of small mammals. Murrelet 26: 24-26.

Schultz, M.A. \& Klomp, N.I. 2000: Chick-provisioning behaviour of two shearwaters breeding in south-eastern Australia. Austral Ecology 25: 319-326.

Serventy, D.L., Serventy, V. \& Warham, J. 1971: The Handbook of Australian Sea-birds. Reed, Sydney, Australia: 254 pp.

Smith, V.R., Avenant, N.I. \& Chown, S.I. 2003: The diet and impact of house mice on a sub-Antarctic island. Polar Biology 25: 703-715.

Storr, G.M., Smith, L.A. \& Johnstone, R.E. 1999: Lizards of Western Australia. I. Skinks. Western Australian Museum, Perth, Western Australia: $291 \mathrm{pp}$.

Strahan, R. (ed.) 1995: The Mammals of Australia. Reed Books, Chatswood, New South Wales, Australia: 756 pp.

Triggs, B. 1996: Tracks, Scats and Other Traces: A Field Guide to Australian Mammals. Oxford University Press, South Melbourne, Australia: $340 \mathrm{pp}$.

Whicker, A.D. \& Detling, J.K. 1988: Ecological consequences of prairic dog disturbances. Bioscience 38: 778-785.

Whitaker, P.B. \& Shine, R. 2002: Thermal biology and activity patterns of the eastern brown snake (Pseudonaja textilis): A radiotelemetric study. Herpetologica 58: 436-52.

Whitford, W.G. \& Kay, F.R. 1999: Biopedturbation by mammals in deserts: a review. Journal of Arid Environments 41: 203-230. 
Whittow, G.C., Pettit, T.N., Ackerman, R.A. \& Paganelli, C.V. 1987: Temperature regulation in a burrow-nesting tropical seabird, the Wedge-tailed Shearwater (Puffinus pacificus). Journal of Comparative Physiology B 157: 607-614.

Withers, P.C. 1992: Comparative Animal Physiology. Saunders College Publishing, Orlando, Florida, USA: $949 \mathrm{pp}$.

Wolfe, K.M. 2004: Ecological relationships between the dibbler, Parantechinus apicalis, and burrowing seabirds on two islands in Jurien Bay, Western Australia. PhD Thesis. School of Animal Biology, Universiry of Western Australia, Perth, Western Australia. Unpublished.

Wolfe, K.M., Mills, H.R., Garkaklis, M.J. \& Bencini, R. 2004 Post-mating survival in a small marsupial is associated with nutrient inputs from seabirds. Ecology 85: 1740-1746.

(accepted 5 August 2007) 